\title{
A METHODOLOGY TO ASSESS THE GENERIC COMPETENCE "ANALYSIS AND PROBLEM SOLVING" IN MASTER DEGREE
}

\author{
María-José Verdecho, Pedro Gómez-Gasquet, Raúl Rodríguez-Rodríguez, Juan- \\ José Alfaro-Saiz
}

Department of Business Organization, Universitat Politècnica de València (SPAIN)

\begin{abstract}
The Universitat Politècnica de València (UPV) has considered the development and assessment of generic competences in the curricula of its undergraduate and graduate degrees. Specifically, thirteen generic competences have been defined and introduced within all the curricula. These generic competences are to be assessed within the specific activities developed through the courses. For that purpose, the UPV has designed an institutional project called "UPV transversal competences" in order to guide the general implementation of the generic competencies in the degrees. This paper emerges from the work developed within a specific educational project designed in coherence with the institutional UPV project that studies the "analysis and problem solving" competence in master degree.

Instructors have experience in the assessment and development of specific competences but, most of them, still need tools that aid to assess the degree of development of generic competences due to its novelty in the curricula. In order to fill this gap, this paper presents a structured methodology to design and develop assessment procedures and instruments of the "analysis and problem solving" generic competence. This methodology has been applied during the academic year 2015-2016 to assess the "analysis and problem solving" competence in the "Technologies and Software Applications for Supply Chain Management" course which belongs to the Master in Advanced Engineering Production, Logistics and Supply Chain at the Higher Technical School of Industrial Engineering. This paper discusses main results and conclusions obtained from the application. These results are of two types: results of the assessment of the specific competence in the course and results of the questionnaire passed to the students to know their point of view regarding the whole experience.
\end{abstract}

Keywords: generic competence, higher education, analysis and problem solving, master, assessment tools.

\section{INTRODUCTION}

The Universitat Politècnica de València (UPV) has defined the development and assessment of generic competences in the curricula of its undergraduate and graduate degrees. Specifically, thirteen generic or transversal competences (TC) have been defined and introduced within all the curricula [1]:

- TC-1 Understanding and integration

- TC-2 Application practical thinking

- TC-3 Analysis and problem solving

- TC-4 Innovation, creativity and entrepreneurship

- TC-5 Project design

- TC-6 Teamwork and leadership

- TC-7 Professional and ethical responsibility

- TC-8 Effective communication

- TC-9 Critical thinking

- TC-10 Knowledge of contemporary issues

- TC-11 Continuous learning

- TC-12 Planning and time management

- TC-13 Instrumental specific 
These generic competences are to be assessed within the specific activities developed through the subjects/courses. For that purpose, the UPV has designed an institutional project called "UPV transversal competences" in order to guide the general implementation of the generic competencies in the degrees. This paper emerges from the work developed within a specific educational project designed in coherence with the institutional UPV project that studies the TC3 - Analysis and Problem Solving competence in master degree. In [2], Analysis and Problem Solving competence is defined as "identify, analyse and define the significant elements that constitute a problem in order to solve it with criterion and in an effective manner". This competence aims to improve the confidence of the student in its own thinking; improve the skills and capabilities to learn, understand and apply knowledge and; favour the achievement of a high degree of individual autonomy that allows him/her to continue the learning process. The problems are new situations that demand that people answer with new behaviours. In order to solve a problem, several tasks are to be done demanding more or less difficult reasoning processes.

The UPV has defined different learning outcomes for every transversal competence depending on the year of the studies. There are three categories: first and second year of the degree, third and fourth year of the degree and master/graduate studies. That is because as the students pass the different courses, the degree of requirement and development of the generic competence has to increase. Then, there are three levels of domain for every transversal competence depending on the year of the studies. The level I corresponds for undergraduate studies (first and second year of the degree). Level II corresponds for undergraduate studies (third and fourth year of the degree). Finally, level III corresponds to master/graduate studies. The learning outcome for the Analysis and Problem Solving competence at master level (level III) is "to solve problems in individual and/or team manner, in different contexts and different complexity from different approaches" [3].

Instructors have experience in the assessment and development of specific competences but, most of them, still need tools that aid to assess the degree of development of generic competences due to its novelty in the curricula. In order to fill this gap, this paper presents a structured methodology to design and develop assessment procedures and instruments of the "analysis and problem solving" generic competence. This methodology has been applied during the academic year 2015-2016 to assess the "analysis and problem solving" competence in the "Technologies and Software Applications for Supply Chain Management" course which belongs to the Master in Advanced Engineering Production, Logistics and Supply Chain at the Higher Technical School of Industrial Engineering.

This paper is structured as follows. First, the methodology is presented. Second, the design of the learning activity is presented. Third, the assessment instrument is exposed. Fourth, the pilot application is described. Fifth, results are presented. Finally, the conclusions of the paper are exposed.

\section{METHODOLOGY}

The methodology used in this work comprises four stages and it is shown in Figure 1:

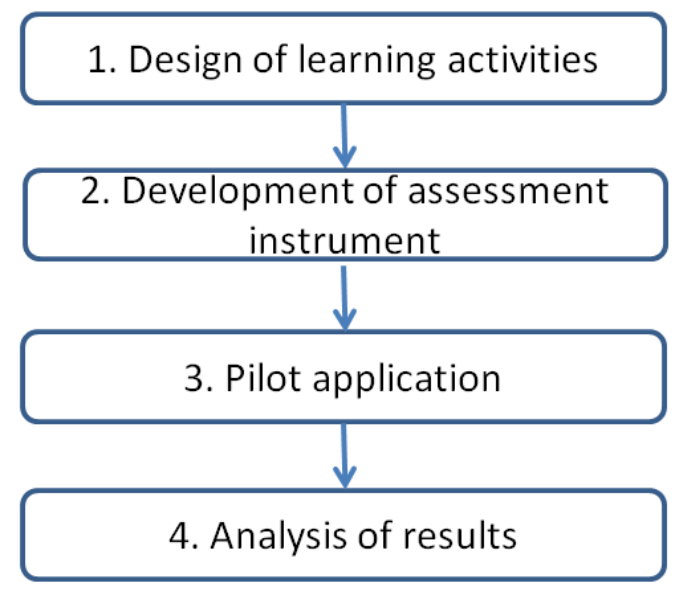

Figure 1. Stages of the methodology 


\section{DESIGN OF LEARNING ACTIVITIES}

The activity to assess corresponds to Unit 4 of the course "Technologies and Software Applications for Supply Chain Management". Unit 4 title is Decision support systems for supply chain contexts in which the Promethee-Gaia method is applied. The objectives of the assignment are:

- Review scientific literature regarding applications within supply chain contexts.

- Select one the papers in order to model the problem.

- Define the multi-criteria problem.

- Apply the Promethee-Gaia method.

- Analyse cause-result impacts.

- Develop alternatives-scenarios.

- Use complementary information.

- Use software to solve the problem.

- Use a systematic approach within all the problem definition-resolutions steps.

- Expose conclusions.

The time required to complete the work is about 25 hours. The materials needed to perform the activity are the class materials and the software application. The course is scientific oriented and this academic year counts with 9 students.

\section{DEVELOPMENT OF THE ASSESSMENT INSTRUMENT}

An instrument is developed for assessing the "analysis and problem solving" competence of the students. This assessment instrument is to be used by the instructor but it is published at the beginning of the course in the intranet to be available to the students so that they know the items that are evaluated by the instructor. Table 1 shows the instrument.

Table 1. Assessment instrument

Assessment instrument to grade the assignments according to the level $(A-D)$ that best describes the student performance.

\begin{tabular}{|c|l|}
\hline Level 1 & Not reached \\
\hline Level 2 & Developing \\
\hline Level 3 & Good \\
\hline Level 4 & Excellent \\
\hline
\end{tabular}

\begin{tabular}{|c|l|l|l|l|l|}
\hline Item Nr. & Item description & 1 & 2 & 3 & 4 \\
\hline 1 & $\begin{array}{l}\text { Defines the problem with precision describing in a clear and } \\
\text { concise manner the most important facts (data) and variables }\end{array}$ & & & \\
\hline 2 & $\begin{array}{l}\text { Analyses the causes and effects of problems from a global } \\
\text { long-term approach }\end{array}$ & & & \\
\hline 3 & Designs systematic procedure to make decisions & & & \\
\hline 4 & $\begin{array}{l}\text { Evaluates possible solutions according to its scientific and } \\
\text { technical feasibility }\end{array}$ & & & \\
\hline 5 & $\begin{array}{l}\text { Applies advanced search criteria information for } \\
\text { troubleshooting and evaluates the quality of information }\end{array}$ & & & \\
\hline
\end{tabular}




\section{PILOT APPLICATION}

An oral exposition is performed by the students once they have established the main problem description and characteristics. In this oral session, all the assignments are reviewed and any doubt is clarified so that the students are able to complete their work. In addition, the assessment instrument is evaluated by the students by using a satisfaction questionnaire of 5-point in Likert scale (1- strongly disagree, 2- disagree, 3- undecided, 4- agree, 5- strongly agree). This questionnaire has been developed by using SurveyMonkey webpage and allows not only to define the questionnaire but also to obtain the results of it. Table 2 shows the satisfaction questionnaire.

Table 2. Satisfaction questionnaire

\begin{tabular}{|c|c|c|c|c|c|}
\hline & 1 & 2 & 3 & 4 & 5 \\
\hline \multicolumn{6}{|l|}{ The assessment procedure is suitable } \\
\hline \multicolumn{6}{|l|}{ The assessment instrument is suitable } \\
\hline \multicolumn{6}{|l|}{ Overall satisfaction with the assessment } \\
\hline \multicolumn{6}{|c|}{ Notes: Comment any aspect you consider relevant to the assessment. } \\
\hline \multicolumn{6}{|c|}{$\begin{array}{l}\text { Would you implement this instrument to assess similar works? } \\
\text { Justify your answer. }\end{array}$} \\
\hline
\end{tabular}

\section{ANALYSIS OF RESULTS}

Once the pilot is performed, two types of results were obtained: results of the questionnaire passed to the students to know their point of view regarding the whole experience and results of the assessment of the specific competence in the course.

\subsection{Results of the satisfaction questionnaire}

Table 3 shows the results of the satisfaction questionnaire. As can be observed, all the students agree with the assessment procedure, assessment instrument and overall satisfaction with the assessment.

Table 3. Results of satisfaction questionnaire

\begin{tabular}{|c|c|c|c|c|c|c|c|}
\hline & 1 & 2 & 3 & 4 & 5 & Total & $\begin{array}{l}\text { Weighted } \\
\text { Average }\end{array}$ \\
\hline $\begin{array}{l}\text { The assessment procedure is } \\
\text { suitable }\end{array}$ & $\begin{array}{l}0 \% \\
0\end{array}$ & $\begin{array}{l}0 \% \\
0\end{array}$ & $\begin{array}{l}0 \% \\
0\end{array}$ & $\begin{array}{l}44.44 \% \\
4\end{array}$ & $\begin{array}{l}55.56 \% \\
5\end{array}$ & $\begin{array}{l}100 \% \\
9\end{array}$ & 4.56 \\
\hline $\begin{array}{l}\text { The assessment instrument is } \\
\text { suitable }\end{array}$ & $\begin{array}{l}0 \% \\
0\end{array}$ & $\begin{array}{l}0 \% \\
0\end{array}$ & $\begin{array}{l}0 \% \\
0\end{array}$ & $\begin{array}{l}66.67 \% \\
6\end{array}$ & $\begin{array}{l}33.33 \% \\
3\end{array}$ & $\begin{array}{l}100 \% \\
9\end{array}$ & 4.33 \\
\hline $\begin{array}{l}\text { Overall satisfaction with the } \\
\text { assessment }\end{array}$ & $\begin{array}{l}0 \% \\
0\end{array}$ & $\begin{array}{l}0 \% \\
0\end{array}$ & $\begin{array}{l}0 \% \\
0\end{array}$ & $\begin{array}{l}66.67 \% \\
6\end{array}$ & $\begin{array}{l}33.33 \% \\
3\end{array}$ & $\begin{array}{l}100 \% \\
9\end{array}$ & 4.33 \\
\hline
\end{tabular}

Regarding the field for commenting any aspect of the assessment, eight out of nine students agree the instrument should be used as it is. One out of nine students indicates that "agree with using an instrument as it for assessing the work but it would be better to clarify some aspects of it". 
Finally, regarding the question if they would you implement this instrument to assess similar works, eight out of nine students said that they will implement it but one out of nine indicated that "first, it is better to detail each assessment item". It has to be noted that the aim of the instructor was to have a complete as well as easy to use instrument but this observation will be taken into account for next applications.

\subsection{Results of the assessment of the analysis and problem solving competence}

The degree reached by the students in the analysis and problem solving competence is shown in Table 4. As can be observed, all the students have a positive degree of achievement of the competence and there is not a single item with grade 1. The item with lower grade (weighted average is 2.56) is the Item Nr. 2 "Analyses the causes and effects of problems from a long-term approach", probably because it is the most complex item for them. In addition, Items Nr. 1 and 5 obtain a grade of 2.67 mainly due to the lack of degree of definition of the facts and variables in the problem and the use of advances search criteria information for troubleshooting. The item with higher grade is Item Nr.3 standing a grade of 3.44. As previous years this instrument was not used for the assessment, it is necessary to compare results qualitatively. Based on the experience of instructors, the initiative can be evaluated as satisfactory and it will be used for future works.

Table 4. Results of the assessment

\begin{tabular}{|c|c|c|c|c|c|c|c|}
\hline $\begin{array}{l}\text { Item } \\
\text { Nr. }\end{array}$ & Item description & 1 & 2 & 3 & 4 & Total & $\begin{array}{l}\text { Weighted } \\
\text { Average }\end{array}$ \\
\hline 1 & $\begin{array}{l}\text { Defines the problem with precision } \\
\text { describing in a clear and concise } \\
\text { manner the most important facts } \\
\text { (data) and variables }\end{array}$ & & $\begin{array}{c}44.44 \% \\
4\end{array}$ & $\begin{array}{c}44.44 \% \\
4\end{array}$ & $\begin{array}{c}11.11 \% \\
1\end{array}$ & $\begin{array}{c}100 \% \\
9\end{array}$ & 2.67 \\
\hline 2 & $\begin{array}{l}\text { Analyses the causes and effects of } \\
\text { problems from a global long-term } \\
\text { approach }\end{array}$ & & $\begin{array}{c}55.56 \% \\
5\end{array}$ & $\begin{array}{c}33.33 \% \\
3\end{array}$ & $\begin{array}{c}11.11 \% \\
1\end{array}$ & $\begin{array}{c}100 \% \\
9\end{array}$ & 2.56 \\
\hline 3 & $\begin{array}{l}\text { Designs systematic procedure to } \\
\text { make decisions }\end{array}$ & & & $\begin{array}{c}55.56 \% \\
5 \\
\end{array}$ & $\begin{array}{c}44.44 \% \\
4 \\
\end{array}$ & $\begin{array}{c}100 \% \\
9\end{array}$ & 3.44 \\
\hline 4 & $\begin{array}{l}\text { Evaluates possible solutions } \\
\text { according to its scientific and } \\
\text { technical feasibility }\end{array}$ & & $\begin{array}{l}22.22 \% \\
2\end{array}$ & $\begin{array}{c}44.44 \% \\
4\end{array}$ & $\begin{array}{c}33.33 \% \\
3\end{array}$ & $\begin{array}{c}100 \% \\
9\end{array}$ & 3.11 \\
\hline 5 & $\begin{array}{l}\text { Applies advanced search criteria } \\
\text { information for troubleshooting and } \\
\text { evaluates the quality of information }\end{array}$ & & $\begin{array}{c}44.44 \% \\
4\end{array}$ & $\begin{array}{c}44.44 \% \\
4\end{array}$ & $\begin{array}{c}11.11 \% \\
1\end{array}$ & $\begin{array}{c}100 \% \\
9\end{array}$ & 2.67 \\
\hline
\end{tabular}

\section{CONCLUSIONS}

The assessment of generic or transversal competences has been introduced in the curricula of UPV undergraduate and graduate programs. Many of these competences were not introduced in the old programs so that instructors lack of tools that aid to assess them.

The UPV has designed an Institutional project that guides the development and implementation of assessment mechanisms to evaluate the degree of achievement of each competence by the students. In coherence with that project, this work presents a methodology that aids to design and develop assessment procedures and instruments of the "analysis and problem solving" generic competence. This methodology has been applied during the academic year 2015-2016 to assess the "analysis and problem solving" competence in the "Technologies and Software Applications for Supply Chain Management" course which belongs to the Master in Advanced Engineering Production, Logistics and Supply Chain at the Higher Technical School of Industrial Engineering.

It is necessary to modify some aspects but results of the initiative show good results in the performance of students as well as positive recommendation from students to be implemented for the 
assessment of the "analysis and problem solving" competence. However, it is still necessary to test this type of instruments in other pilots. In the second semester, it will be used in two other courses of the same master.

\section{ACKNOWLEDGEMENTS}

This work has been developed within the research project called "Assessment of UPV generic competence "problem analysis and resolution" in master students" (Ref.: PIME-A7-15) funded by the Vice-Rectorate for Studies, Quality and Accreditation at Universitat Politècnica de València.

\section{REFERENCES}

[1] Dimensiones competenciales UPV (n.d.). Marco UPV de definición y evaluación de adquisición de competencias. Vicerrectorado de Estudios, Calidad y Acreditación. Downloaded 20 October, 2014, http://www.upv.es/contenidos/ICEP/info/DimensionesCompetenciales.pdf

[2] A. Villa, \& M. Poblete (2007). Aprendizaje basado en competencias. Una propuesta para la evaluación de las competencias genéricas. Vicerrectorado de Innovación y Calidad de la Universidad de Deusto: Ediciones Mensajero.

[3] L. Atarés, A. Baviera, S. Calvet, J. Carballiera, C. Escriba, E. García, R. Llorente, MJ. Muñoz, C. Palao, R. pastor \& E. Valero (2015). Rúbrica UPV CT-3 Análisis y Resolución de Problemas. 